\title{
Migration in the Context of a Multination State: Language Policies, Division and Intolerance in South Tyrol
}

\author{
Luana Franco Rocha ${ }^{a}$ \\ Débora Amaral Costa ${ }^{b}$
}

\begin{abstract}
The aim of this contribution is to situate South Tyrol among other multination states as Flanders, Québec, and Catalonia, as an attempt to broad the models of multi-level governance especially in what regards the accommodation of migrants. Furthermore, this paper shows how language policies affect migrants settled in this Italian multinational context, presenting data collected in semi-structured interviews that show the perspective of migrants towards the policy of declaration of linguistic affiliation or aggregation and division in society. The topics of racism and xenophobia were also raised by the participants, relating to linguistic issues of non-legitimation of the speaker. The outcomes showed that migrants perceive the policy of declaration as a burden, since part of the participants interviewed claim that they do not feel represented by this policy, which enhances social division.
\end{abstract}

Keywords: Migration. Multination state. Language policy.

Recebido em: 23/10/2020 Aceito em: 03/12/2020

a Free University of Bozen-Bolzano, Bolzano, Itália. E-mail: luana.francorocha@education.unibz.it

b Universidade Federal Fluminense, Laboratório de Pesquisas em Contato Linguístico, Niterói, RJ, Brasil; Secretaria Municipal de Edução do Rio de Janeiro, RJ, Brasil. E-mail: debora.costa888@gmail.com

How to cite:

Rocha, L. F.; Costa, D. A. Migration in the Context of a Multination State: Language Policies,

Division and Intolerance in South Tyrol. Gragoatá, Niterói, v.26, n.54, p. 326-354, 2021.

<https://doi.org/10.22409/gragoata.v26i54.46918> 


\section{Introduction}

Located in the Northeast part of Italy, on the border with Austria and Switzerland, the Autonomous Province of BozenBolzano, also known as South Tyrol, is a very fruitful region for multidisciplinary studies on language contact and policies. As this territory was part of the Austro-Hungarian Empire until the end of the first World War, the province has a geohistorical background that led to the coexistence of three ethnolinguistic groups: German, Italian and Ladin, the latter being a RhaetoRomance language. After many years of oppression, especially during Mussolini's dictatorship, the Second Autonomy Statute of 1972 was implemented to guarantee the rights of Ladin and German ethnolinguistic groups through language policies within a consociational model of governance (BAUR, 2000; PALLAVER, 2008). Besides these three autochthonous groups, data from the provincial statistical institute shows that 9,7\% of the South Tyrolean population is composed of migrants (ASTAT, 2020), what contributes to an even more diverse society. Due to these characteristics, one may say that the province of Bozen-Bolzano is a state that is not only multinational, but also polyethnic (KYMLICKA, 2013). Multinational because of its several nations living in a single territory due to the conquests of war, and polyethnic because of its diversity as a result of individual or family immigration. In what concerns the definition of nation, Kymlicka (KYMLICKA, 2013, p. 11) defines it as a historical community occupying a certain territory and sharing the same language and culture. Having presented this background, the aim of this contribution is to situate South Tyrol among other multination states and to show how language policies affect migrants settled in this Italian multinational context.

The theme of this paper, which is part of the first author's ongoing doctoral study, will be unfolded in four parts, as follows. First, we will introduce the panorama of some multination states and how they deal with the dynamics of migration. Secondly, the focus will be on South Tyrol, presenting its language policies and the division in society. Afterwards, we will show the perspective of migrants towards these policies and how they situate themselves in this divided scenario. Finally, we will briefly discuss the issue of racism, 
xenophobia, and how these topics are related to language studies.

The methodology used in this research involves Costa's (2020) narrative-based approach to the studies of migration in Linguistic fields, whose objectives were intertwined with the analysis of linguistic materiality on migration. In this sense, the author developed a methodology for the analysis of representation in which "narratives of migrants were created by the immigrants and further connected to the construction and negotiation of identities, taking as a case study the immigration of Haitians to the city of Rio de Janeiro" (COSTA, 2020, p. 22).

\section{Migration and Multination States}

According to Zapata-Barrero and Barker (2014), there are three main possible forms of administration of Multination States: centralist, cooperative or asymmetric. In a centralist administration, policies are established and implemented mainly by the central government, without major interventions by other levels of government. In the cooperative scenario, there is still a predominance of the central government, including greater collaboration on the part of the regional, provincial or local government when implementing these policies. Finally, in the asymmetric scenario, both the central government and the other levels of government work together to establish and execute these norms, in order to take into account the specificities of the community in which the policy will be implemented. Regarding migration policies in multilevel governance contexts, Zapata-Barrero and Barker (2014 also consider three main dimensions: admission, reception, and citizenship policies. The first deals with the entry of new citizens, legislating on who can or cannot be admitted to the territory. The second concerns the policies that define how these newcomers will be received and integrated into the host community. Finally, citizenship policies legislate on who can receive the status of citizen of the host country and how. According to the authors,

[i]n general, we hypothesize that as we move from citizenship to admissions to reception policy, there is a greater logic in, and probability of, allowing the sub-state level to participate 
not just in implementing, but also in deciding policy. This is so, on one hand, because, as the logic of subsidiarity suggests, reception policies that deal with concrete matters relating to migrants' integration patterns and their relationship with the communities in which they live are arguably most appropriately addressed at the sub-state level (ZAPATABARRERO; BARKER, 2014).

This is to say, considering that policies for admission and granting of citizenship may affect the sovereignty of a country, there is a lower probability that regional, provincial or local governance participate in this decision-making process. Nevertheless, receptions policies are more likely to be designed and implemented by sub-state levels of governance or in combination between central and sub-states governances in order to better fit the local needs. Having considered that, we will briefly present the contexts of Flanders, in Belgium, Catalonia, in Spain, and Québec, in Canada, adding the South Tyrolean scenario within the panorama of these multination states.

In the case of Flanders, there is a combination of a strong centralist governance with a devolutionary administration in what concerns the integration of newcomers (ADAM; JACOBS, 2014). The regional parliament states that migrants who established in Flanders should follow some steps in order to get integrated into the new society. It is the so-called 'Guidance for newcomers (civic integration path)', which was implemented in 2004 and is evaluated every three years in order to assess whether the measures are efficient and how they can be improved (PULINX, 2008). According to the document, newcomer adults living in a municipality located in the Flemish region and having a permit to stay longer than three months must follow this path, which includes a sixty hours course that focus on life, work, norms and values, as well as an elementary Dutch course (PULINX 2008). According to Loobuyck and Jacobs (2009, p. 36), although there is still some discussion if the teaching of values are an effort to enhance social cohesion or if it is an assimilationist attempt to erase migrant's culture, the authors consider this integration policy in Flanders as hybrid, because it combines both assimilationist and multiculturalist aspects. 
In Québec, the provincial government has great autonomy to legislate due to its asymmetric governance. For having an autonomous selection process for migrants (except for refugees and their families), the province can find candidates who best fit the needs of the region, in terms of work, and also those who have the best chance of being integrated into the local culture. Thus, the Québec Immigration Act is the document that regulates not only the selection of newcomers but also their integration. The Act highlights the role of migrants in the contribution to the vitality of the French language in the province and it provides the teaching of democratic and Québec values (QUÉBEC, 2016/2020, chapter 1, section 1). One may not disregard the fact that one of the reasons that leads this Canadian province to consider migrant as part of the valorization of the French language in the territory is its policy of selection of migrants, which prioritizes individuals who already speak French, facilitating Québec's francization purposes. Finally, as far as citizenship is concerned, even though Québec is not allowed to manage the policies linked to this matter, Canada values the country's plurality of identity in this assignment (IACOVINO, 2914, p. 93).

The case of Catalonia is probably the one that most resembles that of South Tyrol due to its cooperative governance. This is to say that the central government regulates admissions and citizenship policies, while the government of the autonomous community of Catalonia legislate on the reception of migrants through their own integration law. Similarly of the Flanders context, where migrants must acquire basic knowledge of Dutch, in Catalonia, the local language is also put in a place of high importance for the integration of newly arrived citizens, being considered the main language for integration in the community (PARLAMENT DE CATALUNYA, 2010, Article 9). Thus, according to the Law on Reception of Immigrants and Returnees to Catalonia (Ibidem), newcomers must learn both Catalan and Castilian language and, in addition, they might as well apply for courses aimed at professional training and basic knowledge about Catalan society and culture.

In the case of South Tyrol, it can be said that the provincial government system works cooperatively with the Italian central government. This means that, while policies oriented to the admission and recognition of citizenship of migrant people 
are under the responsibility of the central government, the policies of reception and integration of these new citizens are elaborated and implemented in a collaborative way between the central and provincial government. Thus, as with the other multination states presented, there is a law in South Tyrol that acts on how migrants are received and integrated into the territory. According to the provincial law on the integration of migrants citizen, mutual knowledge between the different cultures and identities present in the territory should be enhanced, as well as the knowledge of local history and culture to promote the process of integration of newcomers, avoiding a possible ghettoisation (PROVINCIA AUTONOMA DI BOLZANO, 2011, article 11, paragraph 3). In what concerns language policies for migrants, differently to the situation in Flanders and Catalonia, there is no obligation to learn a certain local language nor all of them, what gives more freedom to newcomers to choose the language or languages they want to learn. In addition, notions about South Tyrolean society and culture should be promoted as well.

It should be noticed that, although Article 7 of the Provincial Law (Ibidem) says that it shall be encouraged the learning of all three provincial languages (German, Italian, and Ladin), Article 2 states that the responsibility for coordinating the measures for the integration of migrants lies with the Provincial Department for the Right to Study, German Culture and Integration. Thus, as there is no mention of any kind of participation by the Italian or Ladin department, one may assume that language and culture teaching activities may be oriented exclusively - or at least mostly - towards Germanspeaking culture, even though studies shows that most immigrants prefer to use the Italian language in everyday life (MEDDA-WINDISCHER et al., 2011). Furthermore, some additional deliberations changed the original text of the law, linking compulsory language and citizenship course to the possibility to acquire benefits considered as not indispensable (GIUNTA PROVINCIALE, 2018), as well as specifying the nature of the languages courses (GIUNTA PROVINCIALE, 2017). According to the latter, even saying that the teaching of the three territorial languages should be fostered, Deliberation 816 points to the offer of free courses in only two languages: 
${ }^{1}$ Common European

Framework of

References for

Languages
German and Italian, in forty hours of course at levels A1 and A2 according to the CEFRL ${ }^{1}$ (Ibidem).

Language being a major element of a community's identity, McAndrew (2013) will say that in multinational states there is generally great concern about the protection of autochthonous minorities in view of the arrival of allophone migrants. Thus, although one might imagine that in a multicultural context there could be a greater willingness to welcome new citizens, according to Kymlicka (2011, p. 289), "countries with an inherited ethos of accommodation in relation to old minorities are not predestined to be inclusive of new minorities". For this reason, these regional or provincial laws for the reception of new citizens are so based on language policies, as observed above.

Therefore, while the policy of migrants' reception in Flanders proposes a policy of compulsory Dutch courses for adult migrants, In Catalonia, there is an obligation to acquire basic knowledge of both the Castilian and Catalan languages. As for Québec, since there is a system that selects the migrants who will settle in the region, access is prioritized for those who already speak French. Finally, in South Tyrol, there is greater flexibility in the sense that the new citizen can freely choose one or more local languages to learn. However, the administration of the Bolzano-Bozen Province is institutionally divided among its three ethnolinguistic groups, with the responsibility for the integration program being solely that of the province's German language and culture department, which may give priority to teaching German over Italian and Ladin languages. In the following section, we will consider the language policies of South Tyrol, where we will point out precisely the source of this institutional division.

\section{Language Policies and Division in South Tyrol}

After the official annexation of South Tyrol to Italy in October 1920, under the fascist regime of Mussolini, German and Ladin ethnolinguistic groups, were oppressed by a set of decrees that aimed a process of Italianization of the region. In an attempt to erase the linguistic and cultural traits of these minority groups, these laws banned the use of their language by implementing a reform at schools including only Italian 
${ }^{2}$ The original text states as follow: "ogni cittadino di età superiore $\mathrm{ad}$ anni quattordici, non interdetto per infermità di mente e residente nella provincia di Bolzano alla data del censimento, è tenuto a rendere, in forma anonima, una dichiarazione individuale di appartenenza ad uno dei tre gruppi linguistici italiano, tedesco e ladino. Coloro che ritengono di non appartenere ad alcuno dei predetti gruppi lo dichiarano e rendono soltanto dichiarazione anonima di aggregazione ad uno di essi". language, as well as the completely abolition of German and Ladin toponyms for towns, rivers, mountains, family names and even gravestones (BAUR, 2000, p. 34-35). In order to find an agreement between Austria and Italy, in September 1946, the Paris Peace Treaty was signed, giving hope to German and Ladin-speaking groups by a partially autonomous administration of the region. Thus, the creation of the First Autonomous Statute of 1948 was the initial step to protect the minority groups. Nevertheless, the Italian government continued to push and attack German and Ladin-speaking communities, disrespecting the Peace Treaty, which led to a troubled period of violence and struggle for more autonomy (Ibidem, p. 41). Finally, after many negotiations, the solution found was to implement a Second Autonomous Statute, in 1972, which gave more autonomy to South Tyrol, including the creation of a consociational model of governance that could represent the three groups settled in the territory based on a quota system: the Proportionality.

The policy of Proportionality was implemented in order to allow all three ethnolinguistic groups to participate in the provincial governance with a balanced representativity. This is to say that the idea was to establish a more equitable form of authority based on a system of proportional quotas in two main areas: the positions in public administration and the distribution of resources for welfare, social and cultural measures. According to Article 89 of the Second Statute of Autonomy (GIUNTA PROVINCIALE DI BOLZANO, 2019 p. 115), this proportion is organized based on a Declaration of linguistic affiliation or aggregation to be submitted anonymously during the linguistic census, which takes place in the province every ten years. Thus,

every citizen over fourteen years old, not interdicted for insanity of mind and resident in the province of Bolzano at the date of the census, is required to make, anonymously, an individual declaration of belonging to one of the three language groups Italian, German and Ladin. Those who believe that they do not belong to any of these groups should declare it and make only an anonymous declaration of aggregation to one of them ${ }^{2}$ (ITALIA, 1976, article 18). 
Therefore, according to this norm, citizens living in South Tyrol during the census must declare themselves as members of the Italian, German, or Ladin group. If they do not feel that they belong to one of these three groups, the solution given by the province is to aggregate to one of the three groups instead of affiliating themselves. In both situations, the choice is always between Italian, German, or Ladin language groups, without the option of picking 'other' nor more than one option. Thus, according to data of the last census (ASTAT, 2012), the South Tyrolean population consists of $26.06 \%$ of people who declared themselves to be members or affiliated to the Italian group, $69.41 \%$ to the German group, and $4.53 \%$ to the Ladin group.

Having the data regarding the number of people who declare themselves part of each of the three linguistic groups, the number of public positions is assigned according to this proportion to both provincial and municipal governments. In the same way, funds allocated to welfare, social and cultural activities are also distributed according to this proportion. As far as education is concerned, the province has three different school systems, corresponding respectively for each of the three ethnolinguistic groups, and the funds are likewise divided according to the proportion of speakers of each group. Furthermore, to obtain the benefits linked to a specific group - such as public employment or welfare assets as social housing - the citizen must demonstrate that he/she is part of the target ethnolinguistic group by submitting to the Court a personal and individual declaration of linguistic affiliation or aggregation in one of the three mentioned groups. This personal declaration will be stored in an anonymous envelope at the provincial Court and may be consulted each time the person needs to prove his/her language group for the purposes explained above. As a way to avoid possible maneuver strategies, although the document can be modified at any time, it will only become valid after eighteen months from the last submission date (ITALIA, 1976, article 20/ter, item 4).

It is interesting to perceive that, while in Belgium linguistics census are banned since 1962 in such a manner to avoid conflicts between French and Flemish speakers (WITTE, 2011), in South Tyrol, the data that shows the dimension of each linguistic group is not only widely publicized but is also the basis for the consociational government. Notwithstanding, 
Belgium and South Tyrol actually have something in common: a society divided by ethnolinguistics aspects. Similar to South Tyrol, there is in Belgium an important and explicit division in society, mainly because of the linguistic separatism of schools (McANDREW, 2013):

[T] he level of prejudice and stereotyping is relatively high among both French- and Dutch-speaking youth. [...] However, it is difficult to distinguish what in these attitudes is a result of segregated schooling and what can be attributed to other factors such as family socialization or media coverage (McANDREW, 2013, p. 30).

Thus, both contexts show school systems that are separated by language groups, which can collaborate in the process of socializing individuals within speakers of the same language, making multilingual relationships more difficult. Going in the same direction, Rautz (2001, p. 760) will state that the separatist school model present in South Tyrol indeed corroborates to the division of society, fulfilling the function of the protection of minorities and placing the two groups side by side in a peaceful existence, while it makes it more difficult for the two main groups to live together.

As in South Tyrol there is a separate administrative sector for cultural promotion for each language group, funds for activities are also split, thus promoting few multicultural and multilingual initiatives. In that sense, not only is the school system divided into language groups, in fact, in South Tyrol this division is so deeply embedded in the way of life of the society that it pervades almost every aspect of social life, as sports clubs, cultural associations and even religious associations (ZINN, 2018, p. 57). On the other hand, the linguistic division in Belgium occurs with a more geographically border, since the country has been explicitly divided into four linguistic areas: French, Dutch, bilingual, and German-speaking zones (SINARDET, 2008). Thus, similarly to South Tyrol, people belonging to different language groups do not live together in daily life; instead, they are distanced by a governmental administrative structure of separatism. Thus, although the policy of Proportionality has been created in South Tyrol in order to guarantee the rights of minorities and their inclusion in governance, it actually creates a deep institutional division 
in society (LANTSCHNER; POGGESCHI, 2008, p. 220; PALLAVER, 2001).

Another element that enhances this division is the linguistic barrier. Even though one may think that in a multination state as South Tyrol all inhabitants are bi or trilingual, Negro (2005, p. 116) will state that reality does not confirm this statement. According to her,

what such a language policy has defended and implemented so far is monolingualism: each citizen (German, Italian, and, partly, Ladin) has the right to grow up and live in a totally monolingual context. Besides, the sociolinguistic picture of South Tirol is complicated by the fact that the German speaking community is diglossic and that the code mostly used in conversation is a Bavarian dialect, whereas the Italian minority (very composite as regards the regional origin of its members) virtually dispenses with dialects and uses standard Italian in all formal and informal contexts (NEGRO, 2005, p. 116-117).

Certainly, the fact that the language used in everyday life by German speakers is in fact a Bavarian dialect and not standard German makes it more difficult for Italian speakers to learn the language. This is because, except for a few occasional initiatives, both in schools and in private courses, the variation of German taught is the standard and not the dialect, which may cause communication problems. On the one hand, German-speakers from the most diverse age ranges make daily use of a wide variety of dialects of Bavarian origin, on the other hand, the Italian-speaking community shows a more uniform dialect, which is very close to the language considered standard (CICCOLONE, 2016). According to Baur (2000, p. 43) this occurs mainly because of the fascist project of Italianization of the province, when people from different parts of Italy settled in South Tyrol, without having any cultural and dialectal element that bonded them. Therefore, while the German-speaking group has the advantage of learning the language of the other, since there is no strong dialectal difference, Italian speakers usually report having more difficulty communicating with people who speak Germanic dialects even though they have studied standard German.

Therefore, the sociolinguistics panorama of South Tyrol is highly complex considering only the autochthonous 
communities. If the matter of the migrant population settled in the province is added, this question becomes even more intricated. Especially in what regards the declaration of linguistic affiliation o aggregation, which only allows the choice of one of the three autochthonous ethnolinguistic groups, it may be a very delicate issue when dealing with migrants with a different linguistic and cultural background, as well as people from the so-called mixed families, i.e., families composed of individuals from different ethnolinguistic groups. According to Zinn (2018),

[w]ith the Declaration, the essentialization of language as the definitive marker of ethnic identity and the reification of group membership become totalizing: as noted above, there is no option for persons with multiple language competences or children of 'mixed marriages' between Italian and German speakers. The quandaries of the Declaration are even more apparent when the respondents are naturalized foreigners residing in South Tyrol, who are requested to either declare membership in one of the groups or 'affiliate' themselves to one (ZINN, 2018, p. 63)

Thus, essentialize the linguistic and cultural diversity present in the province in only one of the three language groups may cause uneasiness for people speaking other languages, as well as those who are proficient in two or more languages. According to Wright (2004, p. 280), "[language] is one of the stronger markers of identity because there are cognitive as well as psychological barriers to be overcome when individuals shift language. An outsider cannot decide to join a linguistically distinct group simply by willing it". Hence, one may notice that the policy of declaration does not consider the whole plurality of the province, since it represents neither bi/ trilingual individuals nor allophone migrants, as we will see in the next section.

\section{The perspective of migrants}

On this section we will present the perspective of adult migrants living in South Tyrol concerning the policy of declaration of linguistic affiliation or aggregation and its consequent division in society. For this purpose, this paper is based on the data obtained from twenty individual semi-structured interviews with migrants from different 
backgrounds, conducted between February 2019 and August 2020 in the cities of Bolzano-Bozen, Meran-Merano and BrixenBressanone. Although the reduced number of participants, the data show relevant information to understand the dynamics of migration in the context of a multination state. The interviews were carried out in several languages, according to the preference of the interviewees; however, the transcriptions presented here were freely translated into English by the authors in order to facilitate the reading of the paper.

As discussed in the previous section, the power-sharing model of governance implemented in South Tyrol is based on the declaration that citizen must provide stating that he/she takes part to one of the three ethnolinguistic groups: Italian, German or Ladin. Nevertheless, considering that there is no place provided to assign a fourth language neither further choices such as "other" or "none of the previous options", many citizens with a different linguistic background feel unrepresented. When the participants are asked about the declaration policy, it was possible to verify two distinct types of attitude. If, on the one hand, some participants reported not understanding exactly the purpose of this policy or even a total lack of information regarding the declaration, on the other hand, other participants said they understand the historical reasons that led to this kind of minority protection, although they believe it is nowadays outdated or even unfair to migrants. In the following paragraphs, some excerpts from the interviews will be presented in order to exemplify these stances taken by the participants. All names have been changed to guarantee the anonymity of the participants.

In the case of Amina, an Albanian woman, 31 years old, living for twelve years in South Tyrol, she says that her husband had to submit the declaration once he obtained his Italian citizenship. However, they were not aware of the aim of this document and, according to her, they decided to choose the German group because some of their acquaintances claimed that one might have more advantages choosing this ethnolinguistic group. Raising her shoulders, Amina declares: "What difference does it make, we honestly do not know". The experience of Amina and her family shows two relevant aspects. On the one hand, one may argue that the provincial government is not transparent enough regarding the policy 
of declaration, providing little information about the purpose of this document, especially towards migrant citizens. On the other hand, as the German-speaking community is a majority in South Tyrol and the number of public vacancies, as well as social subsidies, is based on the Proportionality, there is a general speech that it is more convenient to choose the Germanspeaking group. Another important aspect to notice is that some participants reported being completely unaware of the declaration. Although it was not possible to ascertain precisely the reason for this lack of knowledge, it must be noticed that only in the year 2015 foreign citizens were included as eligible to submit the declaration. As such, it is possible to deduce that those who emigrated to South Tyrol before the amendment of this norm were never informed about it by the government.

Concerning the participants who have a greater awareness of the policy, many of them reported that the need to make choices between the three ethnolinguistic groups is not an easy task for those who come from a culture and language other than German, Italian, and Ladin. For Xiomara, for example, a woman original from Venezuela, living for thirteen years in the province of Bozen-Bolzano, the existence of a policy to protect the minority languages of the province in understandable, nevertheless the need to choose between these three groups may be invasive:

At that moment [when the policy was created], because they wanted to protect their language, their culture, so it was, ok... maybe necessary. Now I think that it's not. And for that, at that moment it was invasive for me, because I can't say that I am a native German speaker and I can't say that I am a native Italian speaker. [...] And then now the European Community is asking for possible languages, so you have to invest your time in making people learn Italian better and German better and not to continue with that separation of languages that is now useless. [...] Now the request is different (Xiomara, 42, Venezuelan).

The experience of Klaus, 40 years old and living for more than three years in South Tyrol resembles the one reported by Xiomara. Although he is a native German speaker, he claims that the declaration ends up essentializing the individual, allocating him/her in inflexible categories: 
Let's say that the choice for me was easy, because evidently my mother tongue is German, it would have been much stranger if my language was French. There the choice was easy, but anyway it's always this moment to declare to belong to a category is still a heavy thing, you know? The problem is that: putting on a certain box, you feel stuck in this system (Klaus, 40, German).

With regard to the division of society into ethnolinguistic groups, some participants express a visible perception of tension between the different autochthonous ethnolinguistic groups, in particular between Italian and German speakers. For Aisha, a woman original from Morocco, living for 17 years in the city of Bolzano-Bozen, the declaration policy enhances this division in society:

I find it a bit bizarre at the bureaucratic level, because anyway this distinction between German and Italian remains, doesn't it? And in my opinion local politics feed this division. Instead of finding a policy for cohesion. Instead, they always contribute to it [the division], even by creating these German schools, Italian schools. With this policy, in my opinion it always enhances this division and it's not nice (Aisha, 35, Moroccan).

Another similar position is that of Klaus, who states that this protection of minority groups creates a strong bond between individuals belonging to these groups, but a certain rejection of other groups that compose the society:

Clearly this group creation also produces a certain mental closure. These groups were created precisely for the protection of minorities and this idea of protecting then leads to an exchange within the group, but a closure to everything around, right? (Klaus, 40, German).

Finally, Pedro, a Brazilian man, living for two years in South Tyrol, states that the system of Proportionality and its declaration is a top-down policy that affects social behavior:

I think that this policy of division [...] it's a written norm that generates a social behavior. It comes from a social behavior, from a social value, it becomes a written norm and it reinforces this social behavior, so I see that this generates a little division... I'm not going to tell you that it's permanent, that it affects everyone, but it exists (Pedro, 40, Brazilian). 
Thus, according to Pedro, the institutional division created by the province acts directly on the behavior of the population in order to accentuate the historical tensions that exist mainly among German and Italian speaking people. This idea meets the studies of Baur (2000, p. 128), which states that the political separation promoted by the province has a direct effect on private behavior, creating two parallel societies that only enhance monolingualism and monoculture.

With regard to the way in which migrants experience this dynamic of groups in everyday life, most participants stated that they feel closer to Italian-speakers or other migrants, underlining the stereotype that German-speaking citizens are more reserved in their social groups. According to the majority of the participants, it is more difficult to integrate into the German-speaking group, probably because the signs left by the oppression suffered during the dictatorship still remain in the collective memory of this minority group (BAUR, 2000). To conclude, some participants also experienced a general rejection to migrants, as we will see in the next section.

\section{Racism, xenophobia and the non-legitimate speaker}

In addition to the issues encountered due to the language policies of the province, migrants also face other difficulties in daily life, these related to the intolerance of the host community. Thus, during the interviews, the theme of discrimination was raised spontaneously by some of the participants. Although Bashir, a man original from Pakistan, living in Meran-Merano for eight years, affirmed that he never witnessed any case of racism or xenophobia in the city where he lives, other participants disagree with this statement and report episodes of intolerance not only in Meran-Merano but also in other localities of the province. This is the case of Adeel, also from Pakistan, and living for more than one year in South Tyrol. He emphatically stated that Italian and German speakers do not like migrants in general, although he classifies Italian speakers as more friendly, trying to help foreign citizens. Adeel reports his experience phoning a German-speaking person after seeing the announcement of a car sale in the newspaper. He says: "Once I saw an ad for a car and I called. The woman, German [speaker], noticed that I was a foreigner 
because I couldn't speak Italian or German well and she said I wanted to steal her car" (Adeel, 27, Pakistani). That is to say, the woman on the phone assumed that he was a thief only by the way he was speaking, which we may consider a xenophobic attitude. Finally, Adeel says that foreigners are treated worse just because of their origin and even those who speak good Italian prove more difficult in finding a good job, ending up doing undervalued services.

Furthermore, Fatma, a woman from Morocco, living for eleven years in South Tyrol, tells her experience as a mother of a child attending the German language school. In her emotional speech, she says:

He [her younger son] has problems now, it's not that there is no problem, because it's not easy to enter [the German language school] because the kids always say 'foreigner', always! A 'foreigner of shit' [...] and, above all, German [speaking] children are rude. [...] I remember that many times my son came home crying, you know? They tell you very bad things, even if there's a party, there's something going on, they leave you behind... nothing is missing for us, we're the same, you know? But... here, for me, for my son, when he comes home, I say: 'look, we are the same, even if they tell you things'... This year in the sixth grade, for example, I had a lot of problems with my son because [...] the big boys take the little ones' snacks, and those who say something is beaten up. They don't beat him inside the school, but outside the school... do you understand? It's very serious... [...] I'll tell you one thing, the thing that hurts me very much, that here there's always the ugly thing for foreigners, 'who's the one who dropped this glass? [she points to the coffee that was spilled on the table] The foreigner! Who did that? The foreigner!' is not that all foreigners are nice, but it's always the foreigners who are to blame. [....] It's not that we want to have the life of paradise. But there are some people who don't think like that, who think that foreigners are bad, brutes, who think that foreigners are...I don't know, the ones who make all the noise....and it's not that (Fatma, 45, Moroccan).

Hence, as Adeel stated above, Fatma also reports that she and her son are mistreated only for being migrants. Besides, as a Muslim woman, Fatma affirms that her religion is also perceived as a threat to the host community, which is mostly Catholic. Another situation of discrimination in the environment of a German-speaking school is reported by 
Aisha, this time regarding directly to racial aspects. She talks about the time her son was at school:

He remembers it as the hardest years of his life. [...] Because it was difficult to be accepted. He always came home 'ah... they told me that I have curly hair, they told me that I have a dark color, they told me that, they told me that, they told me...' then... it was difficult, it was a difficult time for him (Aisha, 35, Moroccan).

While Aisha reports a situation of evident racial discrimination in the school context, Amina and Milena, both light-skinned, report having suffered discrimination because of the country they come from, that is to say, Albania and Romania, respectively:

Here you are not like the locals, maybe they also have prejudices. [...] I used to work once, they were all Germans [speakers], I must say, and a few Italians [speakers], two or three, and when they heard that I was Albanian they said 'but how? Really? How did you come to work here? How come they let you in here?' There is one thing that... I don't know... I don't even know if it was a bad thing or for me... boh, a strange thing for them, I don't know...it's just that this situation happened to me, I must say (Amina, 31, Albanian).

Although Amina emphasizes that she is not sure if the question was, in fact, made for xenophobic reasons, she does not feel comfortable with the situation anyway. Milena, in turn, says that although she feels good living in South Tyrol, she reports having gone through some situations of uneasiness, as reported below:

I feel good, even if sometimes it happened to me that I spoke Italian and they looked at me a bit badly, behind me was a German [speaking] woman who was served before me. [...] I spoke Italian and she pretended not to understand, so she asked the person behind me what she wanted. In German. So she attended her and I waited until she finished and then I understood it, right? She was pretending, in my opinion, because how can you not understand Italian? (Milena, 46, Romanian)

According to Ylka, an Albanian woman living for fifteen years in South Tyrol, also the Italian speaker population may go through situations of intolerance in regard to German speakers. 
As she reports, Italian speakers are still seen as the invaders of the German-speaking territory, which, according to her, means that the migrant is not seen as the first enemy but is still seen as inferior. And she continues to tell the following situation:

It happened to me here in my work that a client who understood that I was not Italian, but treated me with a kindness because he thought I was German [speaker]. Then he found out by chance that I am Albanian and he said that 'look, how...' he asked me how I am in this job, considering that this was a work of honor for me, because who would have taken me here? I mean, he made me understand that 'but you were lucky, eh? Because nobody would take an Albanian here.' Then he discovered that I was also a writer, but the same was not enough for him, because being a writer, it was important that it is one from Europe. See where you're going with the judgment (Ylka, 47, Albanian).

The examples reported by Ylka clearly show this position of inferiority in which the migrant is placed by part of the autochthonous community. In Pedro's case, one may perceive a reflection of the typical anti-migrant discourse recurring in the media, that migrants would take over the space of the autochthonous citizen, as if foreigner citizens were somehow exempt from paying taxes:

At the hospital it was where I felt most badly treated, most badly treated indeed, it seems, I had a feeling that... because you weren't local... also when I went to make my document... the health insurance document, I felt the same thing too. It seems like 'wait, are you coming here to use our service?' People didn't make it clear, but they had a dissatisfaction, I don't know if it was just me, because I couldn't check it, but I felt badly attended (Pedro, 40, Brazilian).

Furthermore, participants discuss a topic likewise related to discrimination, although with a close connection to the use of language: the issue of the non-legitimate speaker. When recognized as non-native speakers, either because of the color of their skin, their way of dressing or speaking, migrant people are often categorized as inauthentic or non-legitimate speakers of a certain language, even if they have proven proficiency in that language. This kind of linguistic ideology of authenticity ties language to a given community, attributing an identity value that gives more relevance to who speaks than to what is 
spoken (WOOLARD, 2016, p. 22). Hence, according to this logic, there would be a social construction of a specific pattern of people who would be authorized to speak a certain language, a concept that meets the studies that associate language and race of Fanon (2008) and Rosa and Flores (2017). One may not disregard that there is a great difference between racism and xenophobia, since the former rejects the individual already from his/her physical appearance, while the latter is often not rejected because of his/her phenotype, but in a second instance due to his/her way of speaking or acting. However, in spite of these differences, as far as the linguistic aspect is concerned, there are many similarities, since the migrant, regardless of the color of the skin, is treated as a non-legitimate speaker, not worthy of respect, as one may perceive in the examples provided by the participants.

As a Caribbean black man living in France, Fanon (2008, p. 14) states that white French people address black Frenchspeakers in a childish language, as if the latter were unable to understand standard French. According to the author,

[t]o speak gobbledygook to a black man is insulting, for it means he is the gook. Yet, we'll be told, there is no intention to willfully give offense. OK, but it is precisely this absence of will - this offhand manner; this casualness; and the ease with which they classify him, imprison him at an uncivilized and primitive level - that is insulting (FANON, 2008, p. 15)

Thus, talk in that infantilized and exaggeratedly casual language assuming that the person with whom you are talking will not understand standard language is not only disrespectful, but it also delegitimizes the other's speech. In that sense, Ylka shares her experience in South Tyrol where, according to her, mainly German-speaking people address to migrants using the Italian form of treatment $t u$, used in more informal situations and socially seen as disrespectful when there is no intimacy with the interlocutor. According to Ylka, this occurs mainly when the interlocutor is of African origin:

That is, in common places, especially when they call you $t u$, this is offensive, they do it. They do it with those with whom they understand immediately that they are Italians and above all they do it immediately with African boys, because they can see them from above, so they allow themselves to call them tu (Ylka, 47, Albanian). 
Moreover, she says that this informal treatment is also addressed to her because, although she is phenotypically accepted in the host community, her way of speaking denounces her origin. Ylka states that every time she has to go to the post office, the attendant treats her using the pronoun $t u$. The same occurs with Pedro:

I think it was the most difficult place for social integration I have ever seen. [...] There's a barrier due to the fact that I'm a foreigner, because I don't seem to be a foreigner, but when I speak people realize that I'm a foreigner and they have a whole different behavior (Pedro, 40, Brazilian).

Another way of not giving legitimacy to the speech of migrant people is to assume that non-native speakers do not know the local language. Pujolar (2010) and Woolard (2016) describe this attitude in Catalonia, where speakers of Catalan automatically address non-native speakers in Castilian language, while Zinn (2018) reports that the same fact also occurs in South Tyrol, where speakers of German address presumed non-German speakers in Italian language. This situation is reported by Xiomara, who, despite her high proficiency in German language, claims that the Germanspeaking community usually addresses her in Italian: "When they see me and when they hear that I am a Spanish-speaker, Germans [speakers] also try to speak Italian"(Xiomara, 42, Venezuelan). This attitude demonstrates the delegitimization suffered by migrants, although the efforts to engage in learning the local languages, they continue to be seen as an inauthentic speaker and, following Woolard's logic, if the speaker is not legitimate, then what is spoken is also likely to be disregarded.

Participants of German origin and therefore standard German-speakers, in turn, also report receiving distinct treatment from the autochthonous community. This is mainly due to the Bavarian Germanic dialect, the widely used language in the province, which makes standard Germanspeakers individuals automatically be labeled as inauthentic. As Baur (2000, p.129) explains, the German dialect is seen in South Tyrol as a secret language, used as an identification key to the members of the community, rejecting those who cannot speak it, i.e. usually migrants and Italian speaking persons. 
According to Hannes, a young man originally from Germany, he says that he is treated differently by the host community, even if he speaks German. For Klaus, speaking standard German automatically puts him in a place of not belonging to South Tyrol, creating a different treatment, which he considers as offensive:

When I greet someone, the person knows that I am not South Tyrolean. Immediately, already with the first word and then there are two possible reactions: for the most common is that people try to talk standard German with me and treat you a bit like a foreigner or a tourist, sometimes they also tell me something like 'but, how long do you stay in Bolzano, do you like Bolzano? [...] It's really kind of an offensive system, isn't it? (Klaus, 40, German).

Finally, Paul, also of German origin, realizes that speaking standard German may cause a distancing of the autochthonous community:

So I always have the feeling that when I speak standard German, I am always treated as a... as the German, as the newcomer, and when one speaks dialect, then there is a closeness. [...] So when you speak standard German, then you... sudden create a distance, I have the feeling (Paul, 37, German).

Therefore, some participants perceive a difference in language treatment due to the fact that they are migrants, even when they are native speakers of German. Finally, this idea, which conceives only a specific pattern of speakers as legitimate to use a certain language puts the migrant speaker in an inferior position towards the autochthonous community, delegitimizing their speech.

Furthermore, the situations of intolerance discussed in this section corroborates Kymlicka's (2011) statement presented above, i.e., that indeed multination states may show an even more challenging context for the integration of migrants. According to McAndrew (2013),

when language is playing a central role in the identity of a group that experienced becoming a sociological minority, the behaviours and performance of newcomers will be 
particularly scrutinized. The situation could be marked by anxiety if language relations are such that the immigrant populations tend to adopt the traditionally dominant language (McANDREW, 2013, p. 112).

Thus, the fear of losing their identity and the rights achieved by a long past of mobilization symbolized by the Second Statute of Autonomy may have created a society that establishes boundaries not only between the autochthonous population, because of the institutional division through the quota system, but also between host community and newcomers.

\section{Conclusion}

The policy of Proportionality and its consequent declaration of linguistic affiliation or aggregation is for sure a major achievement to the minority groups in South Tyrol in view of the dramatic past of annulment of rights and deprivation of self-identity of these populations during the fascist regime. Notwithstanding, with the recent migration flows, the province of Bozen-Bolzano has become even more diverse, being considered not only as a multination state, but also a polyethnic one (KYMLICKA, 2013). Therefore, having a policy of declaration that includes only one of three language options may be considered quite restrictive in light of the multiplicity of languages and cultures that composes South Tyrol nowadays. Besides, this paper showed that also from the perspective of migrants the declaration is seen as a burden, since part of the participants interviewed claim that they do not feel represented by this policy, which indeed enhances social division. Thus, the exercise of placing South Tyrol among the context of research on multination states is an attempt to broaden the models of multi-level governance especially in what regards the accommodation of migrants.

To conclude, it is necessary to think about a new language policy for South Tyrol that encompasses the diversity present in the territory in such a way to respect the rights of old and new minorities (MEDDA-WINDISCHER; CARLÀ, 2013). Hence, it would be worthwhile to foster educational projects based on the ideas of the education for liberation (FREIRE, 2014), encouraging the encounter between speakers of German, 
Italian, Ladin and allophones in such a way to develop strategies that stimulate empathy and solidarity, as well as the combat of xenophobia and racism.

\section{REFERENCES}

ADAM, Ilke; JACOBS, Dirk. Divided on immigration, two models for integration. The multilevel governance of immigration and integration in Belgium. In: HEPBURN, Eve., ZAPATA-BARRERO, Ricard (eds.). The politics of immigration in multi-level states: Governance and political parties. Palgrave politics of identity and citizenship series. Basingstoke: Palgrave Macmillan, 2014. p. 65-85.

ASTAT. Astat info nr. 43. Ausländische Wohnbevölkerung 2019/ Astat info nr. 43. Popolazione straniera residente 2019. Bolzano: Provincia Autonoma di Bolzano/ Alto Adige, 2020

Volkszählung 2011. Berechnung des Bestandes der drei Sprachgruppen in der Autonomen Provinz Bozen-Bolzano / Censimento della popolazione 2011. Determinazione della consistenza dei tre gruppi linguistici della Provincia Autonoma di Bolzano-Alto Adige. Bolzano: Provincia Autonoma di Bolzano/Alto Adige, 2012

BAUR, Siegfried. Le insidie della vicinanza: Comunicazione e cooperazione in situazioni di maggioranza / minoranza ; l'esempio dell'Alto Adige. Educazione bilingue 22. Merano: Alpha \& Beta, 2000.

CICCOLONE, Simone. Italian and German in contact: Some macro- and microsociolinguistic observations in Alto Adige (South Tyrol). Quaderns D'Italià, n.21, p. 27-44, 2016.

COSTA, Débora. Identities of Migration: A Narrative-based Approach to the Studies of Social Representation. Berlin: Peter Lang, 2020.

FANON, Frantz. Black skin, white masks. New York: Grove Press, 2008. 
FREIRE, Paulo. Pedagogy of the Oppressed: 30th Anniversary Edition. New York: Bloomsbury Publishing, 2014.

GIUNTA PROVINCIALE DI BOLZANO (Ed.). Manuale dell'Alto Adige con lo statuto di autonomia. Bolzano: Cooperativa Ex Libris, May 28, 2019. Available at http://www.provincia.bz.it/politicadiritto-relazioni-estere/autonomia/downloads/manuale-altoadige.pdf. Access Oct. 17, 2020.

GIUNTA PROVINCIALE. Delibera n. 902. Bolzano-Bozen, September 11, 2018. Available at http://lexbrowser.provinz. bz.it/doc/it/213739/delibera_11_settembre_2018_n_902.aspx. Access October 17, 2020. . Delibera n. 816. Bolzano-Bozen, July 25, 2017. Available at http://lexbrowser.provinz.bz.it/doc/ it/208400/delibera_25_luglio_2017_n_816.aspx. Access October 17, 2020.

IACOVINO, Raffaele. Canadian federalism and the governance of immigration. In: HEPBURN, Eve.; ZAPATA-BARRERO, Ricard (Eds.). The politics of immigration in multi-level states: Governance and political parties. Palgrave politics of identity and citizenship series. Basingstoke: Palgrave Macmillan, 2014. p. 86-107.

ITALIA. Decreto del Presidente della Repubblica 26 luglio 1976, n. 752. Lex: Norme di attuazione dello statuto speciale della Regione Trentino-Alto Adige in materia di proporzionale negli uffici statali siti nella Provincia di Bolzano e di conoscenza delle due lingue nel pubblico impiego. Gazzeta Ufficiale n. 304, Roma, Nov 15, 1976. Available at http://lexbrowser. provinz.bz.it/doc/it/dpr-1976 752/decreto_del_presidente_ della_repubblica_26_luglio_1976_n_752.aspx?view=1. Access on Oct 17, 2020.

KYMLICKA, Will. Multicultural citizenship: A liberal theory of minority rights. Oxford political theory. Oxford: Clarendon, 2013.

Multicultural citizenship within multination states. Ethnicities, 11, 3, p. 281-302, 2011. http://doi. org/10.1177/1468796811407813 
LANTSCHNER, Emma; POGGESCHI, Giovanni. Quota system, census and declaration of affiliation to a linguistic group. In: WOELK, Jens; PALERMO, Francesco; MARKO, Joseph (Eds.). Tolerance through law: self governance and group rights in South Tyrol. Leiden: Martinus Nijhoff Publisher, 2008. p. 219-234.

LOOBUYCK, Patrick; JACOBS, Dirk. Nationalism, multiculturalism and integration policy in Belgium and Flanders. Canadian Issues, p. 29-40, 2009.

McANDREW, Marie. Fragile majorities and education: Belgium, Catalonia, Northern Ireland, and Quebec. Montreal : McGillQueen's Univ. Press, 2013.

MEDDA-WINDISCHER, Roberta; CARLÀ, Andrea (ed.) Politiche Migratorie e Autonomie Territoriali: Nuove Minoranze, Identità e Cittadinanza in Alto Adige e Catalogna/ Migrationspolitik und Territoriale Autonomie: Neue Mindereheiten, Identität unsdStaatsbürgerschaft in Südtirol und Katalonien. BozenBolzano: Eurac Research, 2013.

MEDDA-WINDISCHER, Roberta et al. Condizione e prospettive di integrazione degli stranieri in Alto Adige $=$ Standbild und Integrationsaussichten der ausländischen Bevölkerung Südtirols : Relazioni sociali, lingua, religione e valori = Gesellschaftsleben, Sprache, Religion und Wertehaltung. Bozen-Bolzano: Eurac Research, 2011.

NEGRO, Silvia D. Minority languages between nationalism and new localism: the case of Italy. International Journal of the Sociology of Language, n. 174, p. 113-124, 2005.

ROSA, Jonathan; FLORES, Nelson. Unsettling race and language: Toward a raciolinguistic perspective. Language in Society, vol.46, n.5, p. 621-647, 2017.

PALLAVER, Günther. South Tyrol's consociational democracy: between political claim and social reality. In: WOELK, Jens; PALERMO, Francesco; MARKO, Joseph (ed.). Tolerance through law: self governance and group rights in South Tyrol. Leiden: Martinus Nijhoff Publisher, 2008. p. 303-328. 
Euregio Tirolo-Trentino-Alto Adige/Südtirol: un progetto a cavallo fra politica e diritto. In: MARKO, Joseph; ORTINO, Sergio; PALERMO, Francesco (ed.). L'ordinamento speciale della provincia autonoma di Bolzano. Padova: Cedam, 2001. p. $943-858$.

PARLAMENT DE CATALUNYA. Llei 10/2010, del 7 de maig. Lex: Llei d'acollida de les persones immigrades i de les retornades a Catalunya. Diari Oficial de la Generalitat de Catalunya n. 5629. Barcelona, May 14, 2010. Available at: https:// www.parlament.cat/document/nom/TL111.pdf. Access Oct. 17, 2020.

PROVINCIA AUTONOMA DI BOLZANO. Legge Provinciale n. 12. Lex: Integrazione delle cittadine e dei cittadini stranieri. Bolzano-Bozen, October 28, 2011. Available at http:// lexbrowser.provinz.bz.it/doc/it/194047/legge_provinciale_28_ ottobre_2011_n_12.aspx?view=1. Access Oct.17, 2020.

PUJOLAR, Joan. Immigration and language education in Catalonia: Between national and social agendas. Linguistics and Education, vol.21. p. 229-243, 2010.

PULINX, Reinhilde. Living together in diversity - Linguistic integration in Flanders. Council of Europe: Language Policy Division, 2008. Available at http://rm.coe.int/09000016802fc1d7. Access Oct. 17, 2020.

QUÉBEC. Québec Immigration Act. Québec: Québec Official Publisher, 2016, updated to June 14, 2020. Available at http:// legisquebec.gouv.qc.ca/en/showDoc/cs/I-0.2.1?\&digest=. Access Oct. 17, 2020.

RAUTZ, Günther. (2001). Il sistema scolastico. In: MARKO, Joseph; ORTINO, Sergio; PALERMO, Francesco (Eds.). L'ordinamento speciale della provincia autonoma di Bolzano. Padova: Cedam, 2001. p. 746-760.

SINARDET, Dave. Territorialité et identités linguistiques en Belgique. Hermès, La Revue, v.51, n.2, p.141-147, 2008. Available at https://www.cairn.info/revue-hermes-la-revue-2008-2page-141.htm. Access on Oct 17, 2020. 
WITTE, Els. La question linguistique en Belgique dans une perspective historique. Pouvoirs, v. 136, n. 1, p. 37-50, 2011. Available at: https://doi.org/10.3917/pouv.136.0037

WOOLARD, Kathryn. Singular and plural: Ideologies of linguistic authority in $21^{\text {st }}$ century Catalonia. Oxford Studies in the Anthropology of Language. Oxford: Oxford University Press, 2016.

WRIGHT, Sue. Language policy and language planning: From nationalism to globalisation. London: Macmillan, 2004.

ZAPATA-BARRERO, Ricard; BARKER, Fiona. Multilevel Governance of Immigration in Multinational States: 'Who Governs?' Reconsidered. In: HEPBURN, Eve.; ZAPATABARRERO, Ricard (Eds.). The politics of immigration in multi-level states: Governance and political parties. Palgrave politics of identity and citizenship series. Basingstoke: Palgrave Macmillan, 2014. p. 19-40.

ZINN, Dorothy L. Migrants as Metaphor. Migrazioni. Roma: CISU, 2018. 


\section{Resumo}

\section{Migração em contexto de estado} multinacional: políticas linguísticas, divisão e intolerância no Tirol do Sul

O objetivo desta contribuição é situar o Tirol do Sul, entre outros estados multinacionais como Flandres, Québec e Catalunha, como uma tentativa de ampliar os modelos de governo em multiníveis, especialmente no que diz respeito à acomodação de migrantes. Além disso, este artigo mostra como as politicas linguísticas afetam os migrantes que vivem nesse contexto multinacional italiano, apresentando dados recolhidos em entrevistas semiestruturadas que mostram a perspectiva dos migrantes no que concerne à política de declaração de filiação ou agregação linguística e de divisão na sociedade. Os tópicos de racismo e xenofobia foram também levantados pelos participantes, sendo relacionados com questões linguísticas de não- legitimação do falante. Os resultados mostraram que os migrantes veem a politica de declaração como um fardo, uma vez que parte dos participantes entrevistados afirma que não se sentem representados por esta política, a qual reforça a divisão social.

Palavras-chave: Migração. Estado multinacional. Politica linguística.

Luana Rocha é Mestre em Estudos de Linguagem pela Universidade Federal Fluminense e atualmente é doutoranda na Free University of Bozen-Bolzano, tendo realizado um período dos seus estudos na Universitat Oberta de Catalunya. Seus temas de pesquisa envolvem Sociolinguística, Políticas Linguísticas e Migração.

Débora Costa é Doutora em Letras pela Universidade Federal Fluminense. Realizou doutorado em co-tutela com a Europa Universität Viadrina (Frankfurt Oder). Atua na Secretaria Municipal de Educação do RJ como professora de Língua Portuguesa e de Língua Inglesa. É autora do livro Identities of Migration. 